\title{
A study of cases reported as incidents in a public hospital from 2011 to 2014
}

\author{
Estudo dos casos notificados como incidentes em um hospital público de 2011 a 2014 \\ Estudio de los casos notificados como incidentes en un hospital público de 2011 a 2014
}

Leila Bernarda Donato Göttems ${ }^{1,2}$, Maria do Livramento Gomes dos Santos², Paloma Aparecida Carvalho ${ }^{3}$, Fábio Ferreira Amorim ${ }^{4}$

How to cite this article:

Göttems LBD, Santos MLG, Carvalho PA, Amorim FF. A study of cases reported as incidents in a public hospital from 2011 to 2014 . Rev Esc Enferm USP. 2016;50(5):861-867. DOI: http://dx.doi.org/10.1590/S0080-623420160000600021

${ }^{1}$ Escola Superior de Ciências da Saúde, Programa de Pós-Graduação Stricto Senso, Brasília, DF, Brazil.

${ }^{2}$ Universidade Católica de Brasília, Brasília, DF, Brazil.

${ }^{3}$ Centro Universitário do Distrito Federal, Brasília, DF, Brazil.

${ }^{4}$ Escola Superior de Ciências da Saúde, Brasília, DF, Brazil.
Corresponding author:

Leila Bernarda Donato Göttems

Edifício Fepecs - SMHN, Quadra 03

CEP: 70710-907 - Brasília, DF, Brazil

leila.gottems@gmail.com

\begin{abstract}
Objective: Analyzing incidents reported in a public hospital in the Federal District, Brasilia, according to the characteristics and outcomes involving patients. Method: A descriptive and retrospective study of incidents reported between January 2011 and September 2014. Results: 209 reported incidents were categorized as reportable occurrences $(\mathrm{n}=22,10.5 \%)$, near misses $(\mathrm{n}=16,7.7 \%)$; incident without injury $(\mathrm{n}=$ $4,1.9 \%)$ and incident with injury (adverse events) $(n=167,79.9 \%)$. The average age of patients was 44 years and the hospitalization time until the moment of the incident was on average 38.5 days. Nurses were the healthcare professionals who most reported the incidents $(\mathrm{n}=55,67 \%)$. No outcomes resulted in death. Conclusion: Incidents related to blood/hemoderivatives, medical devices/equipment, patient injuries and intravenous medication/fluids were the most frequent. Standardizing the reporting processes and enhancing participation by professionals in managing incidents is recommended.
\end{abstract}

\section{DESCRIPTORS}

Patient Safety; Risk Management; Quality of Health Care; Health Services Evaluation. 


\section{INTRODUCTION}

The Incident Reporting System (IRS) is a fundamental tool for improving patient safety ${ }^{(1-2)}$. Although IRS implementation in health services is relatively recent, its importance is well demonstrated through successful experiences in industries operating in environments that can generate high-risk incidents, such as aviation and nuclear power plants ${ }^{(1-4)}$. In the health area, the concept underlying the IRS is relatively simple because obtaining information about risky situations to which patients are exposed during care provision enables understanding/knowledge of how and why they could be injured at an organizational level, allowing for causal factors to be identified and avoided. Thus, this information may provide improvement in services and reduce the likelihood of further incidents occurring ${ }^{(1-2,4)}$.

In the context of the IRS in healthcare, incidents that must be reported are understood as any circumstance or event that resulted or could have resulted in unnecessary injury/harm to the patient's health. It may be a result of intentional or unintentional acts, including mistakes being unintentional incidents by definition ${ }^{(5-6)}$. Damage to health is understood as any impairment of structure or function of the body and/or any effect arising from it, including illness, injury, suffering, disability, impairment or death; it can be physical, social or psychological $^{(6)}$.

The International Classification for Patient Safety is described in 10 classes that provide a comprehensive understanding of the patient safety domain. It aims to represent a continuous learning and improvement cycle, enhancing risk identification, prevention, detection, risk reduction, recovery from the incident and resilience of the system ${ }^{(6)}$.

In this sense, the first two classes (type of incident and consequences for the patient), together are intended to group the incidents of patient safety into categories with clinical significance. The incident type class is a descriptive term for a category that consists of similar natured incidents, and grouped due to shared characteristics in which there is consensus, such as an incident from "medical process/procedure" or "intravenous medication/fluid". The class consequences for the patient contains concepts that relate to the impact on the patient and which are totally or partially attributed to an incident. The consequences for the patient can be classified according to the type of injury/damage, the degree of injury/ damage and the social and/or economic impact ${ }^{(6)}$.

The degree of damage can be classified into: none (the consequence to the patient is asymptomatic or without detected symptoms and does not require treatment); slight (the consequence to the patient is symptomatic, with mild symptoms, loss of function or minimum or intermediate damage of short duration without intervention or with a minimum intervention required); moderate (the consequence to the patient is symptomatic, requiring intervention, increase in hospitalization, causing permanent or longterm injury, or loss of function); severe (the consequence to the patient is symptomatic, requiring intervention to save the life or major medical/surgical intervention, shortening life expectancy or causing major permanent damage or long-term or loss of function); death (death was caused or was shortly anticipated by the incident) $)^{(6)}$.

An incident can be a reportable occurrence, a near miss, an incident without injury or an incident with injury (adverse event). A reportable occurrence is a situation with significant potential to cause injury, but in which there has been no incident (e.g. a defibrillator in the emergency room that is not working); a near miss is an incident that did not reach the patient, but had potential health damage intercepted before it occurred (error in the prescription corrected before the product is administered to the patient); incident without injury is an incident that the patient experienced, but resulted in no discernible injury (transfused unit of blood, but the blood was not incompatible with the patient); incident with injury (adverse event) is an incident resulting in damage arising from health care, unintentional and not related to the natural evolution of the underlying disease, which results in prolonged hospitalization and/or death (transfusion of a wrong unit of blood and eventual death by hemolytic reaction) $)^{(6-7)}$.

Adverse events (AE) have an important impact on the Unified Health System (Sistema Único de Saúde - SUS) which result in increased morbidity, mortality, patient treatment time and care costs, and are reflected in other fields of social and economic life in all countries ${ }^{(8-10)}$. Notifying and acknowledging the existence of AE facilitate investigation of care quality, because failures do happen and are important for evaluating health services ${ }^{(4,7,11-13)}$. Furthermore, the occurrence of $\mathrm{AE}$ constitutes an important factor for evaluating patient safety, which can be understood as reducing the associated risk of unnecessary damage to health care down to a minimum acceptable level ${ }^{(6)}$. Several current studies report a strong link between safety and quality in health ${ }^{(9,11)}$. In this perspective, safety is one of the dimensions of health service quality, being an inseparable attribute $^{(9)}$. Thus, health systems that reduce the risk of injury to the patient to a minimum are undoubtedly increasing the quality of their services ${ }^{(5,9,11)}$.

The aim of this study was to analyze the incidents reported in a public hospital in the Federal District, the characteristics of patients involved, and the outcomes for the patient in the period of 2011 to 2014.

\section{METHOD}

A descriptive and retrospective study of reported incidents was carried out from January, 2011 to September, 2014, in a large public hospital of the Federal District of Brasilia, part of the sentinel hospital network. The research protocol was approved by the Ethics Committee of the Research and Education Foundation in Health Sciences of the Federal District State Department of Health under number 144.024, without the need for signing Clear and Informed Consent Forms given the retrospective nature and non-interventional study.

All incidents reported in sectors of Risk Management and Transfusion Committee during the study period were included, as identified through documental analysis of various reports of notification instruments used by the hospital: 
incident reporting forms, memos and medical notes, AE investigation files, and spreadsheets with summarized information online. After identifying the reported incident, additional information was checked for in the medical records of patients when there was something observed in the notification. Access to this material was obtained at the Hospital Risk Management by the researchers who are nurses and working in the hospital, and by a student of the last period of the nursing course. Data collection was conducted from September, 2014 to October, 2014.

In this set of documents the following data were checked: (1) Patient characteristics: gender, age and hospital stay in days; (2) Incident characteristics: category of the incident (Reportable occurrence, near miss, incident without injury and incident with injury - adverse event), degree of injury (none, mild, moderate, severe, and death), and type of incident (clinical management, clinical process/ procedure, documentation, infections associated to health care, intravenous medication/fluids, blood/hemoderivatives, nutrition, oxygen/gas/vapour, medical devices/medical equipment, behavior, patient accident, infrastructure/ buildings/facilities and resources/organizational management) in accordance with the criteria described and established by the International Classification for Patient Safety of $\mathrm{WHO}^{(7)}$; (3) Professional category of whom notified and (4) Place of occurrence.

We stress that the notification form had an option for the notifier/healthcare professional to indicate whether there was injury to the patient. The degree of injury was classified by the research team (a hospital nurse, a student in their last year of the nursing program, a teaching nurse and researcher at the Universidade Católica de Brasília) at the time of the investigating the patient records.

The descriptive statistical analysis was carried out using the Statistical Package for the Social Sciences (SPSS) software version 21.0.

\section{RESULTS}

209 incidents were reported at the Risk Management unit $(\mathrm{n}=104,49.8 \%)$ and the Transfusion Committee ( $\mathrm{n}=105,50.2 \%)$ in the period between January, 2011 to September, 2014, which are presented according to the category and degree of injury in Table 1.

In $\mathrm{AE}$ with a slight degree of injury, there was a higher incidence of mild transfusion reactions $(n=91,69.5 \%)$, falls $(n=20,15.3 \%)$ and unscheduled enteral feeding withdrawal $(\mathrm{n}=8,6.1 \%)$. In $\mathrm{AE}$ with a moderate degree of injury, there were 10 transfusion reactions (33.3\%), and eight pressure ulcers (2.7\%). In relation to AE degree of severe injury, there were four cases of anaphylactic shock due to transfusion reactions (66.6\%), one fall that resulted in bilateral femur fracture requiring major surgical correction which resulted in increased hospital stay (16.7\%), and one cardiac arrest that occurred after central venous access withdrawal and applying dressing (16.7\%). No AE had death as outcome.

Reported incidents according to the professional category of who reported the incident and the place/site of occurrence are in Table 2.
Table 1 - Incidents occurred according to the category and degree of injury - Brasilia, Distrito Federal, Brazil, 2015.

\begin{tabular}{lcc}
\hline Incidents & N & \% \\
\hline Category & 22 & 10.5 \\
Reportable occurrence & 16 & 7.7 \\
Near Miss & 4 & 1.9 \\
Incident without injury & 167 & 79.9 \\
Incident with injury (adverse event) & & \\
Degree of damage & 42 & 20.1 \\
None & 131 & 62.7 \\
Slight & 30 & 14.3 \\
Moderate & 6 & 2.9 \\
Severe & 0 & 0 \\
Death & $\mathbf{2 0 9}$ & $\mathbf{1 0 0}$ \\
\hline Total & & \\
\hline
\end{tabular}

Table 2 - Incidents according to the professional category of who notified the incident and place/site of occurrence - Brasília, Distrito Federal, Brazil, 2015.

\begin{tabular}{|c|c|c|}
\hline Variable & $\mathbf{N}$ & $\%$ \\
\hline \multicolumn{3}{|l|}{ Professional category } \\
\hline Nurse & 55 & 26.3 \\
\hline Doctor & 12 & 5.7 \\
\hline Professional ombudsman & 5 & 2.4 \\
\hline Nursing technician & 5 & 2.4 \\
\hline Physiotherapist & 3 & 1.4 \\
\hline Pharmacist & 2 & 1 \\
\hline Not informed* & 127 & 60.8 \\
\hline \multicolumn{3}{|l|}{ Place/site of occurrence } \\
\hline Admission & 23 & 11 \\
\hline Psychiatry & 14 & 6.7 \\
\hline Intensive care unit & 14 & 6.7 \\
\hline Emergency Room stalls & 5 & 2.4 \\
\hline Pharmacy & 4 & 1.9 \\
\hline Neurocardiovascular center & 4 & 1.9 \\
\hline Outpatient clinic & 3 & 1.4 \\
\hline Core of the Surgical Center & 3 & 1.4 \\
\hline Emergency & 3 & 1.4 \\
\hline Hemodynamics & 3 & 1.4 \\
\hline Neurosurgery & 2 & 1 \\
\hline Others & 7 & 3.5 \\
\hline Not informed* & 124 & 59.3 \\
\hline Total & 209 & 100 \\
\hline
\end{tabular}

*Data could not be obtained due to incomplete or incorrect completion of notification.

As shown in Table 2, for $60.8 \%(n=127)$ of the cases there was no record of the professional category responsible 
for the notification, and 59.3\% ( $\mathrm{n}=124)$ did not register the location of occurrence of the reported incident. These incidents were collected at the Transfusion Committee, which uses a spreadsheet with different data on the reporting forms used by the Risk Management.

Nurses were responsible for most of the notifications $(26.3 \% ; \mathrm{n}=55)$, followed by doctors $(5.7 \% ; \mathrm{n}=12)$, and the site of the occurrence most cited were the inpatient units $(11 \% ; \mathrm{n}=23)$.

The profile of the patients involved in the incidents without damage or AE is described in Table 3. Blank data were observed across all variables (gender, age, time elapsed from hospital admission to the time of the incident, origin).

Of the 209 cases of incidents studied, 38 were related to reportable occurrences (22) and near misses (16). These are incidents that do not involve patients, thus they do not appear in the tables concerning the patients' profile.

In relation to the types of reported incidents according to the WHO International Classification for Patient Safety ${ }^{(6)}$, there was a higher frequency of incidents related to blood/hemoderivatives ( $\mathrm{n}=105 ; 50.2 \%$ ), followed by medical devices/medical equipment $(n=34 ; 16.3 \%)$, patient accident $(\mathrm{n}=31 ; 14.8 \%)$ and medication/intravenous fluids $(n=21 ; 10 \%)$. In the category of reportable occurrences, the most common incidents were related to medical devices/medical equipment ( $n=19 ; 86.4 \%)$. Regarding a near miss, there was a higher frequency of incidents related to medication/intravenous fluids ( $\mathrm{n}=14 ; 87.6 \%)$. In the category incident without injury, the most frequent notifications were related to intravenous medications/fluids ( $\mathrm{n}=$ $2,50 \%)$. In relation to $\mathrm{AE}$, the majority were related to infusion of blood/hemoderivatives ( $n=105 ; 62.9 \%)$, followed by a patient accident $(\mathrm{n}=31 ; 18.6 \%)$ and medical devices/ medical equipment $(n=14 ; 8.4 \%)$ as shown in Table 4 .
Table 3 - Profile of the patients involved in the incidents without injury and adverse events - Brasilia, Distrito Federal, Brazil, 2015.

\begin{tabular}{lcc}
\hline Profile of patients & N & \% \\
\hline Gender & 82 & 47.9 \\
Female & 67 & 39.2 \\
Male & 22 & 12.9 \\
Not informed* & & \\
Age group & 4 & 2.4 \\
Less than 1 year of age & 9 & 5.2 \\
1 to 15 & 21 & 12.3 \\
16 to 25 & 14 & 8.2 \\
26 to 35 & 23 & 13.4 \\
36 a 45 & 26 & 15.2 \\
46 to 60 & 40 & 23.4 \\
Over 60 & 34 & 19.9 \\
Not informed* &
\end{tabular}

Length of hospital stay until the time of the incident

0 to 5 days $\quad 10 \quad 5.9$

6 to 15 days $\quad 8 \quad 4.6$

16 to 30 days $\quad 11 \quad 6.4$

31 to 40 days $\quad 11 \quad 6.4$

41 to 50 days $\quad 10 \quad 5.9$

51 to 60 days $\quad 7.1$

More than 60 days $\quad 10 \quad 5.9$

Not informed* $\quad 104 \quad 60.8$

Origin

\begin{tabular}{lcc} 
Federal District & 74 & 43.3 \\
Other federal units & 23 & 13.4 \\
Not informed* $^{*}$ & 74 & 43.3 \\
\hline Total & $\mathbf{1 7 1}$ & $\mathbf{1 0 0}$ \\
\hline
\end{tabular}

* Data could not be obtained due to incomplete or incorrect completion of notification.

Table 4 - Classification of incidents by type and category according to the WHO International Classification for Patient Safety - Brasilia, Distrito Federal, Brazil, 2015.

\begin{tabular}{|c|c|c|c|c|c|c|c|c|c|c|}
\hline \multirow[t]{2}{*}{ Types of incidents } & \multicolumn{2}{|c|}{$\begin{array}{l}\text { Reportable } \\
\text { occurrence }\end{array}$} & \multicolumn{2}{|c|}{ Near miss } & \multicolumn{2}{|c|}{$\begin{array}{c}\text { Incident without } \\
\text { injury }\end{array}$} & \multicolumn{2}{|c|}{$\begin{array}{c}\text { Incident with injury } \\
\text { (adverse event ) }\end{array}$} & \multicolumn{2}{|c|}{ Total } \\
\hline & $\mathbf{n}$ & $\%$ & $\mathbf{n}$ & $\%$ & $\mathbf{n}$ & $\%$ & $\mathbf{n}$ & $\%$ & $\mathbf{n}$ & $\%$ \\
\hline Clinical management & 0 & - & 1 & 6.2 & 0 & - & 1 & 0.6 & 2 & 1.0 \\
\hline Clinical process/procedure & 0 & - & 0 & - & 1 & 25 & 10 & 5.9 & 11 & 5.3 \\
\hline Documentation & 0 & - & 0 & - & 0 & - & 0 & - & 0 & - \\
\hline Infections associated to health care & 0 & - & 0 & - & 0 & - & 1 & 0.6 & 1 & 0.5 \\
\hline Intravenous medication/fluid & 0 & - & 14 & 87.6 & 2 & 50 & 5 & 3.0 & 21 & 10.0 \\
\hline Blood/hemoderivative & 0 & - & 0 & - & 0 & - & 105 & 62.9 & 105 & 50.2 \\
\hline Nutrition & 0 & - & 0 & - & 0 & - & 0 & - & 0 & - \\
\hline Oxygen/gas/vapor & 0 & - & 0 & - & 0 & - & 0 & - & 0 & - \\
\hline Medical devices/medical equipment & 19 & 86.4 & 1 & 6.2 & 0 & - & 14 & 8.4 & 34 & 16.3 \\
\hline Behavior & 0 & - & 0 & - & 1 & 25 & 0 & - & 1 & 0.5 \\
\hline Patient accident & 0 & - & 0 & - & 0 & - & 31 & 18.6 & 31 & 14.8 \\
\hline Infrastructure/buildings/facilities & 0 & - & 0 & - & 0 & - & 0 & - & 0 & - \\
\hline Resources/organizational management & 0 & - & 0 & - & 0 & - & 0 & - & 0 & - \\
\hline Total & 22 & 100 & 16 & 100 & 4 & 100 & 167 & 100 & 209 & 100 \\
\hline
\end{tabular}




\section{DISCUSSION}

High AE rates worldwide, the rise in health care costs related to such events and the need to offer quality health services have led to discussions about the need for changes in the organization of health services in order to reduce avoidable injuries, and consequently, health $\operatorname{costs}^{(4-5,8-10)}$.

In Brazil, the concern with the quality of processes, practices and technologies used in health care has been a matter of high government priority in recent years, and has led to instituting a gradual and orderly sequence of actions for patient safety. The amount of reported incidents (209) in the analyzed period (three years) considering that the hospital size ( 650 beds) was below the quantity shown in the literature is worth noting, where rates range between $7 \%$ and $16 \%$ in developed countries ${ }^{(5)}$.

It is also important to emphasize that most studies calculate $\mathrm{AE}$ rates through an active search, which features a proactive method to recognize the incidents. In this study, voluntary notifications were analyzed; meaning a reactive method of recognizing incidents and which tends to find numbers below the actual quantity, since it depends on professionals to inform the occurrences so that they become known. This communication method is considered more useful for inducing behavioral changes, and it allows learning from mistakes; however, it also has limitations due to the time needed, lack of appropriate information systems, fear of litigation, the reluctance of people to report their mistakes, lack of knowledge about the importance of events and a lack of adjustment after the notification ${ }^{(12)}$.

There was a predominance of $\mathrm{AE}$ among the reported incidents, followed by reportable occurrences. In this regard, the literature is divergent as there is a predominance of some type of event over another, depending on the intrinsic characteristics of the studied organization ${ }^{(13-15)}$. Studies in Brazil show a predominance of near miss cases, followed by adverse events and incidents without injury ${ }^{(14)}$; incidents without injury followed by reportable occurrence, adverse events and near misses ${ }^{(15)}$. At the hospital of this study, the higher number of $\mathrm{AE}$ in relation to other types of incidents can be justified for being a teaching hospital with major investment in professional and student awareness activities ${ }^{(15)}$.

Regarding the degree of injury, there was a predominance of moderate and slight injury, with the occurrence of a few cases of severe injury, a finding that is in line with other studies ${ }^{(14-15)}$. No incidents analyzed in this study resulted in death. It is worth emphasizing that this classification refers to $\mathrm{AE}$, as reportable occurrences, near misses and incidents without injury do not cause any damage ${ }^{(6)}$.

Nurses were responsible for most of the notifications, followed by doctors, which is in accordance with a study in Brazil $^{(16)}$. Similarly, the higher occurrence of incidents in inpatient units is in accordance with previous studies ${ }^{(12,17)}$. A study performed in hospitals of Rio de Janeiro showed that $86.2 \%$ of the incidents occurred in inpatient units. Also, a study in a hospital in southern Brazil had 64.8\% of incidents occur in inpatient units out of a total of 755 cases analyzed ${ }^{(12,17)}$.
The types of incidents with higher incidence were related to blood/hemoderivatives, patient accidents, problems with medical equipment and intravenous medications/fluids. Transfusion of hemoderivatives is a complex procedure that is associated with a significant risk of complications, including transfusion reactions such as febrile non-hemolytic and allergic reactions ${ }^{(18-19)}$.

In this study, the incidents related to intravenous medications/fluids had the fourth highest notification frequency. Events related to medications are among the most frequent failures in health care, and the probability of an individual surviving a hospital stay free of these events occurring may vary according to the hospitalization length ${ }^{(16,20)}$. However, in most cases, their occurrences can be avoided in the three main stages of the medication process - prescription, dispense and administration. Thus, updated operating procedures should be developed and made available for dispensing drugs, with special emphasis on the potentially dangerous drugs or of high surveillance; in addition, it is necessary to invest in continuing education proposals for teams to strengthen the safety and non-punitive culture ${ }^{(5,20-21)}$.

The existence of $\mathrm{AE}$ that compromise patient safety is currently a major challenge to improve healthcare quality ${ }^{(10)}$. In this respect, it is important to educate health professionals regarding notification of such events, as well as establish non-punitive management practices, stimulate critical and investigative looks at the flaws in the system, and promote corrections by the service itself through actions aimed at patient safety ${ }^{(5,9,11-14)}$.

One of the limitations of this study refers to the difficulty in retrieving information, especially data relating to notifications in the Transfusion Committee due to the characteristics and differential treatment in relation to the notification mode in this sector. It is recommended to carry out studies in relation to transfusion reactions and other incidents separately in order to better understand its features and the actual notification rate in relation to the expected rate.

The IRS of this hospital enabled obtaining information to support an evaluation of services, development of preventive strategies and strengthening safety culture with consequent prevention of damage to patients' health. However, it was observed that there is still a need to standardize service methods with preparation, dissemination, protocols and standard operating procedure updates, as well as training teams from different care sectors.

\section{CONCLUSION}

The study showed that the hospital in this study still presents a reduced number of notifications in relation to the rates found in the literature. The most frequent incident category was adverse events, with a predominance of slight injury, followed by reportable occurrences, near misses and incidents without injury. The most common type of incidents were related to blood/hemoderivatives, followed by patient accident, which mainly occurred in the hospital's inpatient units. Most of the incidents were reported by nurses and doctors. No incidents analyzed in this study resulted in death. 
It is noted that the IRS of this studied hospital uses more than one instrument for reporting, with differences in information that must be filled out. Improving this system can improve the quality of data that are reported. We suggest disseminating actions, as well as awareness-raising strategies and continuing education of the professionals be strengthened in order to increase the number of notifications, and thus the recognition of potential risks in the studied hospital. Adopting organizational learning strategies about incident occurrence has been widely used for this purpose.

\section{RESUMO}

Objetivo: Analisar os incidentes notificados em um hospital público do Distrito Federal, segundo as características e os desfechos quando envolveram pacientes. Método: Estudo descritivo e retrospectivo dos incidentes notificados entre janeiro de 2011 e setembro de 2014. Resultados: Notificados 209 incidentes categorizados em ocorrência comunicável $(n=22,10,5 \%)$, quase evento $(n=16,7,7 \%)$, incidente sem dano $(n=4,1,9 \%)$ e incidente com dano (eventos adversos) $(n=167,79,9 \%)$. A idade média dos pacientes foi de 44 anos e o tempo da internação até o momento do incidente teve média de 38,5 dias. Os enfermeiros foram os que mais notificaram $(n=55,67 \%)$. Nenhum desfecho resultou em morte. Conclusão: Os incidentes relacionados a sangue/hemoderivados, dispositivos/ equipamento médico, acidentes do doente e medicação/fluidos endovenosos foram os mais frequentes. Recomenda-se padronizar os processos de notificação e potencializar a participação dos profissionais no manejo dos incidentes.

\section{DESCRITORES}

Segurança do Paciente; Gestão de Riscos; Qualidade da Assistência à Saúde; Avaliação de Serviços de Saúde.

\section{RESUMEN}

Objetivo: Analizar los incidentes notificados en un hospital público del Distrito Federal, según las características y los resultados cuando involucraron a pacientes. Método: Estudio descriptivo y retrospectivo de los incidentes notificados entre enero de 2011 y septiembre de 2014. Resultados: Notificados 209 incidentes categorizados en consecuencia comunicable ( $n=22,10,5 \%)$, casi evento ( $n$ $=16,7,7 \%)$, incidente sin daño $(n=4,1,9 \%)$ e incidente con daño (eventos adversos) $(n=167,79,9 \%)$. La edad media de los pacientes fue de 44 años y el tiempo de la estancia hospitalaria hasta el momento del incidente tuvo promedio de 38,5 días. Los enfermeros fueron los que más notificaron $(n=55,67 \%)$. Ningún resultado causó muerte. Conclusión: Los incidentes relacionados con sangre/ hemoderivados, dispositivos/equipo médico, accidentes del enfermo y medicación/fluidos endovenosos fueron los más frecuentes. Se recomienda estandarizar los procesos de notificación y potenciar la participación de los profesionales en el manejo de los incidentes.

\section{DESCRIPTORES}

Seguridad del Paciente; Gestión de Riesgos; Calidad de la Atención de Salud; Evaluación de Servicios de Salud.

\section{REFERENCES}

1. Pham JC, Girard T, Pronovost PJ. What to do with healthcare incident reporting systems. J Public Health Res [Internet]. 2013 [cited 2014 Jan 31];2(3):e27. Available from: https://www.ncbi.nlm.nih.gov/pmc/articles/PMC4147750/

2. Reason J. Human error: models and management. BMJ [Internet]. 2000 [cited 2014 Jan 31];320(7237):768-70. Available from: https:// www.ncbi.nlm.nih.gov/pubmed/10720363

3. MacDonald RD. Articles that may change your practice: crew resource management. Air Med J. 2016;35(2):65-66.

4. Van Spall H, Kassam A, Tollefson TT. Near-misses are an opportunity to improve patient safety: adapting strategies of high reliability organizations to healthcare. Curr Opin Otolaryngol Head Neck Surg. 2015;23(4):292-6.

5. Capucho HC, Cassiani SH De B. The need to establish a national patient safety program in Brazil. Rev Saúde Pública [Internet]. 2013 [cited 2016 Aug 31]; 47(4):791-8. Available from: http://www.scielo.br/pdf/rsp/v47n4/en_0034-8910-rsp-47-04-0791.pdf

6. World Health Organization. Conceptual Framework for the International Classification for Patient Safety: Final Technical Report [Internet]. Geneva:WHO; 2009 [cited 2015 Dec 20]. Available from: http://www.who.int/patientsafety/taxonomy/icps_full_report.pdf

7. Capucho HC. Near miss: quase erro ou potencial evento adverso? Rev Latino Am Enfermagem [Internet]. 2011 [cited 2015 Dec 20];19(5):1272-3. Available from: http://www.scielo.br/pdf/rlae/v19n5/pt_27.pdf

8. Paiva MCMS, Paiva SAR, Berti HW. Adverse events: analysis of a notification instrument used in nursing management. Rev EsC Enferm USP [Internet]. 2010 [cited 2016 Jan 31];44(2):286-93. Available from: http://www.scielo.br/pdf/reeusp/v44n2/en_07.pdf

9. Reis CT, Martins M, Laguardia J. A segurança do paciente como dimensão da qualidade do cuidado de saúde: um olhar sobre a literatura. Ciênc Saúde Coletiva. [Internet]. 2013 [citado 2014 jan. 31];18(7):2029-36. Disponível em: http://www.scielo.br/pdf/csc/v18n7/18.pdf

10. Tomás VS, Chanovas BM, Roqueta F, Alcaraz J, Toranzo T. Evadur: eventos adversos ligados a la assistência em los servicios de urgencias de hospitales españoles. Emergencias [Internet]. 2010 [citado 2014 Jan 31];22(6):415-28. Disponible en: http://www. seguridaddelpacienteyenfermero.com/docs/articulos/articulo_18.pdf

11. Hanskamp-Sebregts M, Zegers M, Vincent C, van Gurp PJ, Vet HC, Wollersheim H. Measurement of patient safety: a systematic review of the reliability and validity of adverse event detection with record review. BMJ Open [Internet]. 2016 [cited 2016 Sep 01];6(8):e011078. Available from: https://www.ncbi.nlm.nih.gov/pmc/articles/PMC5013509/

12. Lorenzini E, Santi JAR, Báo ACP. Patient safety: analysis of the incidents notified in a hospital, in south of Brazil. Rev Gaúcha Enferm. [Internet]. 2014 [cited 2016 Aug 31];35(2):121-7. Available from: http://www.scielo.br/pdf/rgenf/v35n2/1983-1447-rgenf-35-02-00121.pdf 
13. Capucho HC, Arnas ER, Cassiani SHB. Patient safety: a comparison between handwritten and computerized voluntary incident reporting. Rev Gaúcha Enferm [Internet]. 2013 [cited 2014 Jan 31];34(1):164-72. Available from: http://www.scielo.br/pdf/rgenf/v34n1/en_21.pdf

14. Paranaguá TTB, Bezerra ALQ, Silva AEBC, Azevedo Filho FM. Prevalence of no harm incidents and adverse events in a surgical clinic. Acta Paul Enferm [Internet]. 2013 [cited 2014 Jan 31];26(3):256-262. Available from: http://www.scielo.br/pdf/ape/v26n3/en_09.pdf

15. Carneiro FS, Bezerra ALQ, Camargo, Silva AEBC, Souza LP, Paranaguá TTB, Branquinho NCS. Eventos adversos na clínica cirúrgica de um hospital universitário: instrumento de avaliação da qualidade. Rev Enferm UERJ [Internet]. 2011 [citado 2014 jan.31];19(2):204-11. Disponível em: http://www.facenf.uerj.br/v19n2/v19n2a06.pdf

16. Roque KE, Melo ECP. Tempo de internação e a ocorrência de eventos adversos a medicamentos: uma questão da enfermagem. Esc Anna Nery [Internet]. 2011 [citado 2014 jan. 31];15(3):595-601. Disponível em: http://www.scielo.br/pdf/ean/v15n3/a22v15n3.pdf

17. Mendes W, Pavão ALB, Martins M, Moura MLO, Travassos C. Características de eventos adversos evitáveis em hospitais do Rio de Janeiro. Rev Assoc Med Bras [Internet]. 2013 [citado 2014 jan. 31];59(5):421-8. http://www.scielo.br/pdf/ramb/v59n5/v59n5a06.pdf

18. Claro CM, Krocockz DVC, Toffolleto MC, Padilha KG. Adverse events at the Intensive Care Unit: nurses' perception about the culture of no-punishment. Rev Esc Enferm USP [Internet]. 2011 [cited 2014 Jan 31];45(1):162-7. Available from: http://www.scielo.br/pdf/reeusp/ v45n1/en_23.pdf

19. Sharma DK, Datta S, Gupta A. Study of acute transfusion reactions in a teaching hospital of Sikkim: A hemovigilance initiative. Indian J Pharmacol [Internet]. 2015 [cited 2016 Sep 03];47(4):370-4.

20. Silva AEBC, Reis AMM, Miasso AI, Santos JO, Cassiani SHB. Adverse drug events in a sentinela hospital in the State of Goiás, Brazil. Rev Latino Am Enfermagem [Internet]. 2011 [cited 2014 Jan 31];19(2):378-86. Available from: http://www.scielo.br/pdf/rlae/v19n2/21.pdf

21. Duarte SCM, Stipp MAC, Silva MM, Oliveira FT. Adverse events and safety in nursing care. Rev Bras Enferm [Internet]. 2015 [cited 2016 Jan 31];68(1):144-54. Available from: http://www.scielo.br/pdf/reben/v68n1/en_0034-7167-reben-68-01-0144.pdf 